\title{
Listening Practice Influence on the Use of Communication Strategies in Oral Translation
}

\author{
Leila Razmjou \\ Department of English Language and Literature, the University of Tabriz, Iran \\ Javad Afsari Ghazi \\ Department of English Language and Literature, Islamic Azad University, Tehran Central Branch, Iran
}

\begin{abstract}
Effective communication plays an important role in translation. In oral translation, translation major students must understand the meaning well enough to translate orally or employ some strategies to compensate for the lack of their linguistic knowledge. Therefore, the purpose of this study was to find out the types of communication strategies undergraduate students employ during oral translation and examine the relationship between authentic listening materials' practice and employment of these strategies. To this end, 34 senior translation major students were videotaped and represented some CNN news samples in the laboratory and their oral translation performance was recorded, for three weeks, and extracted based on Tarone's taxonomy (1977).The students listened to the audio materials of TOFEL IBT for 5 to 10 minutes a day 4 or 5 times a week at home for two months. Then the same news was represented in the laboratory for three weeks after listening to find whether the frequency of communication strategies has changed and listening materials have affected the frequencies. Despite the unawareness of communication strategies, the students locate them in oral translation. Finally, the statistical results revealed a significant relationship between authentic listening materials' practice and the use of communication strategies.
\end{abstract}

Index Terms-communication, communicative competence, strategic competence, communication strategy, oral translation strategies

\section{INTRODUCTION}

Language is a human characteristic with the power to unite and divide large groups of people. Human beings have entered an age of knowledge and need interaction and communication. Communication is the exchange of ideas, information, etc between two or more people; it is a process, by which a communicator conveys meaning and tries to create understanding. This process requires a vast range of skills in listening, observing, speaking, questioning, analyzing, and evaluating. Berelson and Steiner (1964) argued that "Communication: the transmission of information, idea, emotion, skills, etc., by the use of symbols-words, pictures, figures, graphs, etc. It is the act or process of transmission that is usually called communication" (p.254). For most language learners, the main goal of learning a foreign language is to be able to communicate.

According to Berlo (1960) any communication model has some basic elements: the communication source, the encoder, the message, the channel, the decoder, and the communication receiver. Effective communication starts with hearing and understanding rather than talking and trying to convince. Consequently, developing good listening skill and effective understanding should be an integral part of everyone's personal development. Since listening and understanding play an important role in translation, especially in oral translation, translation major students must understand the meaning well enough to respond to or act upon it. Foreign language learners' especially academic students, despite spending years developing their language competences, have all probably; experience the frustrating feeling of not being able to participate effectively in L2 oral communication (Jamshidnejad, 2011). Faerch \& Kasper (1983b) acknowledge the fact that much communication is conducted without any indication of problematicity because it is concealed (p.235). As second language learners and speakers under the condition of communication demands, learners need communication and interpretation, include university translation courses such as oral translation, as an important requirement in most of activities. Learner's main concern in communication is accuracy and fluency. Once learners concentrate on form or accuracy they will encounter with problems, because a non native speaker dose not master all the language forms and rules. Therefore, when L2 learners recognize that there is a lack of linguistic knowledge in the realm of communication; learners try to solve these problems by using communication strategies to achieve communicative goals.

The primary goal of communication is to share meaning which leads to effective decision-making and problemsolving. As a result, the significance of effectiveness in an interaction and the competence of a communication become more important. But how does one determine the effectiveness and appropriateness of any given interaction? And even more important, how do we know if communication is fulfilled? 


\section{COMMunicAtive COMPETENCE}

The term communicative competence is comprised of two words, the combination of which means competence to communicate. Canale and Swain (1980) develop this notion, identifying four dimensions of communicative competence: grammatical competence (knowledge of what is grammatically correct in a language), sociolinguistic competence (knowledge of what is socially acceptable in a language), discourse competence (knowledge of intersentential relationships), and strategic competence (the knowledge of verbal and nonverbal communication strategies). They think that when once grammatical competence, sociolinguistic competence and discourse competence are developed, learners will be able to communicate effectively in the real world. Brown (1994) maintains that communicative competence is "that aspect of our competence that enables us to convey and interpret messages and to negotiate meanings interpersonally within specific contexts" (p.27). Despite an inadequate command of linguistic knowledge, students or learners necessarily rely upon some plans or strategies to set out communicative goals. It is especially occurred when students or learners have no ready- made solutions to cope with unexpected problems. Canale and Swain (1980) describe strategic competence as providing a compensatory function when the linguistic competence of the language user is inadequate (p.30). In Canale and Swain's definition, strategic competence is called into action to" compensate for breakdowns in communication due to performance variables or to insufficient competence"(ibid).

Bachman (1990) regards strategic competence as a capacity that put language competence into real communication contexts (p.107). According to Bachman (ibid) strategic competence embraces all aspects of the assessment, planning and execution of communicative tasks. He sees strategic competence not only as a component of communicative competence, but also as a more general cognitive capacity.

According to Canale and Swain (1980) strategic competence consists of verbal and non-verbal communication strategies (p.30).

The term communication strategy appeared first in literature in the early of 1970s, which was coined by Selinker (1972), to connect CSs with 'errors in learner's interlanguage system'. Communication strategies are those strategies that a language user or translator makes use of whenever she/ he feels some deficiencies in vocabulary and grammar leading to partial or complete misunderstanding or interruption in communication. Tarone (1980) defines communication strategies as "a speaker's attempt to communicate meaningful content in the face of some apparent deficiencies in the interlanguage strategies and to distinguish them from those that promote learning or language production" (285). Several authors and researchers in this field have written about communication strategies, types of them, and propose new taxonomies of communication strategies from time to time (Tarone taxonomy1977; - Bialystock \&Fröhlich taxonomy 1980; - Corder taxonomy1983; - Faerch \& Kasper taxonomy 1983; - Dornyei \& Scott taxonomy 1997). Despite all the talk about communication strategies in oral translation, the much researches which have been conducted discussing the various aspects and problems of learners of English language, there has been very little or no discussion to the listening practice influence on the use of communication strategies to solve communication problems, an essential component of communicative competence. This study attempted to investigate the types of CSs based on Tarone's (1977/1983) taxonomy, when the students encounter with problems in oral translation, and find whether authentic listening materials' practice may have affected the use of these strategies. For this purpose, the following research questions and corresponding null hypothesis were formed:

Q1: What kinds of communication strategies do University students use during oral translation?

Q2: Is there a significant relationship between authentic listening materials' practice and the use of communication strategies in oral translation?

H02 There is no significant relationship between authentic listening materials practice and the use of communication strategies in oral translation.

\section{METHODOLOGY}

The participants of the study were 34 senior undergraduate translation major students who were studying at Islamic Azad University of Tabriz. Out of the 34 subjects, 23were female and 11 were male. All students fall into the 22-25 age range. They had similar socio-cultural and educational background and had never been to any English speaking country before. All the participants had passed 60 to 65 credits of specific courses and had 15 to 20 credits left to graduate.

\section{Procedure}

The data collection procedure was started at the beginning of the academic year at Islamic Azad University of Tabriz. Before the training started, the students were given a copy of the CNN news for getting familiar with the sample types in this study. These samples were used during two months of self -listening at the laboratory. The aim of giving this copy was to help students to activate their background knowledge and make them think about the different types of the news which may be used in this research. The researcher tried to choose shorter news as much as possible and the news were deliberately chosen in social, entertainment, and family hood areas (because audio materials of TOFEL IBT in the second phase falls in these categories) to meet circumstances of the research. From the second week of the new semester the students were videotaped and their performance in oral translation was recorded to identify the type and frequency of communication strategies, according to Tarone's taxonomy, employed by the students in the laboratory. It continued for three weeks. The aim of this phase was to find out whether or not they were aware of the strategies and 
what is the frequency of the strategies used in oral translation of the English news as a target language. During three weeks all the students were videotaped. Depending on the length of the sentences, structures, and difficult vocabularies which might be used in the sample news, students were asked to translate them orally. The sentences or small chunks of the news were asked to be translated orally either one time, when it was clear, or two or three times. During these three weeks 9 news samples were played at laboratory and students' oral translation were recorded. The recorded data was extracted, through audio listening, and analyzed. Then the frequency and number of instances of communication strategies that were used, extracted from the audio listening of the recorded data, was represented in different categories in tables.

At the second stage students were asked to listen to the audio materials of (TOFEL IBT) over 2 months period. These audio materials were taken from the fourth edition of TOFEL (IBT) written by Jolene Gear and Robert Gear (2006). The aim of listening practice was to help students to strengthen their audition. This process was self listening at home. Students had to often listen, but they should listen for short periods- five to ten minutes. This should happen four or five times a week. Even if they did not understand anything, five to ten minutes was a minor investment. In the time of selflistening process, playing the news was continued once a week in the laboratory.

At the second stage the nature of assignment (self Listening) required some motivation to inspire, challenge and stimulate students. Effective strategy in this case was to maintain the interest that can bring students to the course of the assignment. On the other hand, students did not work for free and need to satisfy a course prerequisite, so there should be something that made students to embrace their work. The researcher asked the instructor of oral translation course to maintain and support the project by appointing 3 marks reward for all the students who participated in this study. This process could convince students to share in activities of the course. In order to control the self-listening process the researcher asked the instructor of the course to provide the researcher with a report of the scores students obtained with regard to the evaluation of their listening, by getting feedback which he has grasped the students' performance, done by their instructor during the course. The percentages of the scores students obtained out of 3 marks reward, are presented in the following table.

TABLE 1

THE STUDENTS' REWARD SCORES

\begin{tabular}{|l|l|l|}
\hline $\begin{array}{l}\text { The number of the } \\
\text { students }\end{array}$ & Reward & Percentages \\
\hline 19 & 3 & 55.88 \\
\hline 10 & 2.5 & 29.41 \\
\hline 3 & 2 & 8.82 \\
\hline 2 & 1 & 5.88 \\
\hline 34 & \multicolumn{2}{|c|}{100} \\
\hline
\end{tabular}

At the third stage, the researcher attended the laboratory after that the two months practice was over. Then the samples of the same news, translating orally by the students were recorded for more analysis. The aim was to find out the influence and significance effect of listening practice process on oral translation of the news. The recording process continued for three weeks, one session in a week. Then the data was extracted and analyzed by audio listening measuring which communication strategies were used by the students.

To make sure the researcher's extracting and analyzing of the recoded data was reliable, the university instructor was asked to rate the recorded data, by audio listening, of two phases of this study based on Tarone's (1977) model. The inter-rater reliability of the two phases was calculated and the result of independent sample test showed that there was no significant relationship between the two ranges of extracted and analyzed data $(\operatorname{sig}=.606>.05)$. It means that there was no difference between the two datasets. The high correlation allowed the researcher to trust this procedure.

TABLE 2 GROUP STATISTICS

\begin{tabular}{|l|l|l|l|l|}
\hline group & $\mathrm{N}$ & Mean & Std. Deviation & $\begin{array}{l}\text { Std. Error } \\
\text { Mean }\end{array}$ \\
\hline VAR00001 t1 & 9 & 12.1111 & 6.50854 & 2.16951 \\
t2 & 9 & 10.3333 & 7.77817 & 2.59272 \\
\hline
\end{tabular}

TABLE 3

INDEPENDENT SAMPLE TEST

\begin{tabular}{|c|c|c|c|c|c|}
\hline & \multicolumn{2}{|c|}{$\begin{array}{l}\text { Levene's Test for Equality of } \\
\text { Variances }\end{array}$} & \multicolumn{3}{|c|}{ t-test for Equality of Means } \\
\hline & $\mathrm{F}$ & Sig. & $\mathrm{t}$ & df & Sig. (2-tailed) \\
\hline $\begin{array}{cl}\text { VAR00001 } & \text { Equal variances } \\
& \text { assumed } \\
& \text { Equal variances } \\
& \text { not assumed }\end{array}$ & .073 & .791 & $\begin{array}{l}.526 \\
.526\end{array}$ & $\begin{array}{l}16 \\
15.517\end{array}$ & $\begin{array}{l}.606 \\
.606\end{array}$ \\
\hline
\end{tabular}




\section{RESULTS}

To answer the question intended to investigate the kinds of communication strategies employed by the students, the excerpts were extracted from the students' performances by audio listening. According to the Tarone's model (1977), communication strategies divided into five main types which were further divided into seven sub-categories, the communication strategies used by the students are reported in tables $4 \& 5$.

TABLE 4

THE DISTRIBUTION OF COMMUNICATION STRATEGIES

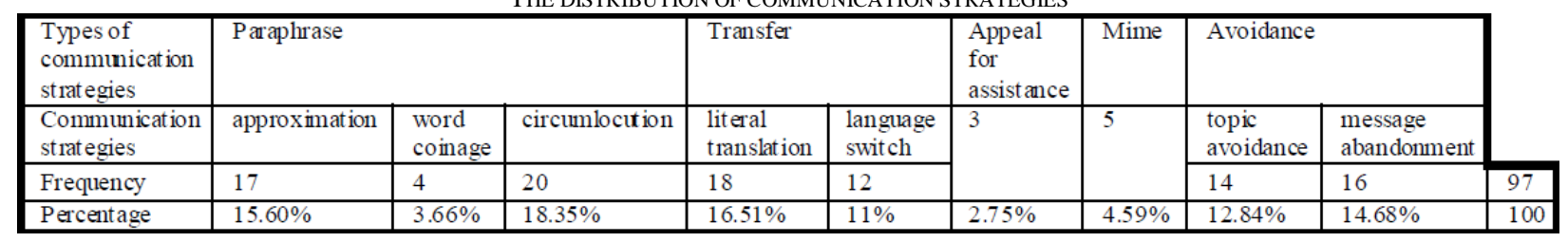

When listening process was over, the same approach was used as it had been used at the first stage. Table 5 showed the result after authentic listening materials' practice.

TABLE 5

THE DISTRIBUTION OF COMMUNICATION STRATEGIES

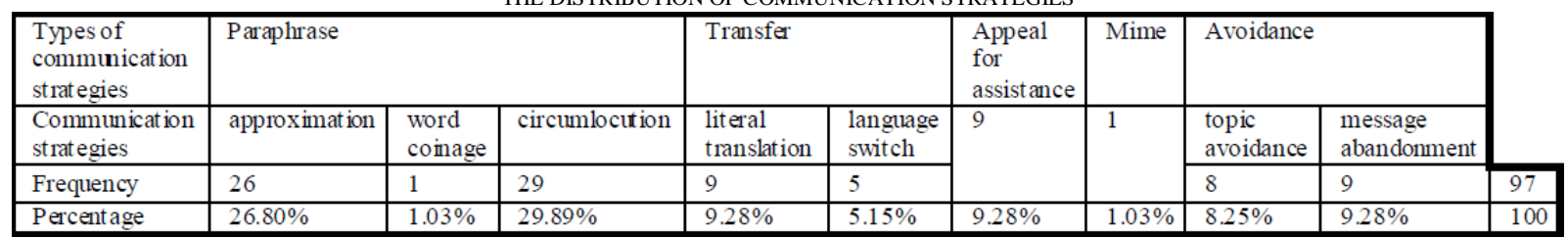

Despite the unawareness of communication strategies, the students locate them in oral translation.

Regarding the second question of this study which covers the authentic listening materials' influence on the use of communication strategies, a null hypothesis was proposed and the result of the data analysis and calculations to test the null hypothesis is as follows:

Table 6 gives a basic picture of how two variables inter-relate.

TABLE 6

TIME * COMMUNICATION STRATEGIES CROSSTABULATION

\begin{tabular}{|c|c|c|c|c|c|c|c|c|c|c|}
\hline & \multicolumn{9}{|c|}{ Communication Strategies } & \multirow[t]{2}{*}{ Total } \\
\hline & $\begin{array}{l}\text { approxi } \\
\text { mation }\end{array}$ & $\begin{array}{l}\text { Word } \\
\text { coinage }\end{array}$ & $\begin{array}{l}\text { circuml } \\
\text { ocution }\end{array}$ & \begin{tabular}{|l|} 
Literal \\
translation
\end{tabular} & $\begin{array}{l}\text { Language } \\
\text { switch }\end{array}$ & $\begin{array}{l}\text { Appeal } \\
\text { for } \\
\text { assistance }\end{array}$ & mime & $\begin{array}{l}\text { Topic } \\
\text { avoidance }\end{array}$ & $\begin{array}{l}\text { Message } \\
\text { abandonment }\end{array}$ & \\
\hline $\begin{array}{l}\text { Time before count } \\
\text { Expected count } \\
\% \text { within } \\
\text { communication } \\
\text { strategies }\end{array}$ & $\begin{array}{l}17 \\
22.8 \\
39.5 \%\end{array}$ & $\begin{array}{l}4.6 \\
80.0 \%\end{array}$ & $\begin{array}{l}20 \\
25.9 \\
40.08 \%\end{array}$ & $\begin{array}{l}18 \\
14.3 \\
66.7 \%\end{array}$ & $\begin{array}{l}12 \\
9.0 \\
70.06 \%\end{array}$ & $\begin{array}{l}3 \\
603 \\
25.0 \%\end{array}$ & $\begin{array}{l}5 \\
3.2 \\
83.3 \%\end{array}$ & $\begin{array}{l}14 \\
11.6 \\
63.6 \%\end{array}$ & $\begin{array}{l}16 \\
13.2 \\
64.0 \%\end{array}$ & $\begin{array}{l}109 \\
109.0 \\
52.9 \%\end{array}$ \\
\hline $\begin{array}{l}\text { Time after count } \\
\text { Expected count } \\
\% \text { within } \\
\text { communication } \\
\text { strategies } \\
\end{array}$ & \begin{tabular}{|l|}
26 \\
20.2 \\
$60.5 \%$
\end{tabular} & $\begin{array}{l}1 \\
2.4 \\
20.0 \%\end{array}$ & $\begin{array}{l}29 \\
23.1 \\
59.2 \%\end{array}$ & $\begin{array}{l}9 \\
12.7 \\
33.3 \%\end{array}$ & $\begin{array}{l}5 \\
8.0 \\
29.4 \%\end{array}$ & $\begin{array}{l}9 \\
5.7 \\
75.0 \%\end{array}$ & $\begin{array}{l}1 \\
2.8 \\
16.7 \%\end{array}$ & $\begin{array}{l}8 \\
10.4 \\
36.4 \%\end{array}$ & $\begin{array}{l}9 \\
11.8 \\
36.0 \%\end{array}$ & $\begin{array}{l}97 \\
97.0 \\
47.1 \%\end{array}$ \\
\hline $\begin{array}{l}\text { Total count } \\
\text { Expected count } \\
\% \text { within } \\
\text { communication } \\
\text { strategies }\end{array}$ & $\begin{array}{l}43 \\
43.0 \\
100 \%\end{array}$ & $\begin{array}{l}5 \\
5.0 \\
100 \%\end{array}$ & $\begin{array}{l}49 \\
49.0 \\
100 \%\end{array}$ & $\begin{array}{l}27 \\
27.0 \\
100 \%\end{array}$ & $\begin{array}{l}17 \\
17.0 \\
100 \%\end{array}$ & $\begin{array}{l}12 \\
12.0 \\
100 \%\end{array}$ & $\begin{array}{l}6 \\
6.0 \\
100 \%\end{array}$ & $\begin{array}{l}22 \\
22.0 \\
100 \%\end{array}$ & $\begin{array}{l}25 \\
25.0 \\
100 \%\end{array}$ & $\begin{array}{l}206 \\
206.0 \\
100 \%\end{array}$ \\
\hline
\end{tabular}

According to crosstabulation, which is the process of creating a contingency table from the multivariate frequency distribution of statistical variables, circumlocution was most frequently used strategy in both phases of the study (before listening process and after listening process). Approximation was in the next range. Appeal for assistance was the least used strategy in the first stage but it changed its place to mime in the second phase.

In order to reject or accept the null hypothesis a chi-square or $\chi^{\wedge} 2$ test was run. A chi square $\left(X^{2}\right)$ statistic was used to investigate whether distributions of categorical variables differ from one another. Table 7 presented the result of $\chi^{\wedge} 2$ test. 
TABLE 7

CHI-SQUARE TEST

\begin{tabular}{|l|l|c|c|}
\hline & Value & df & $\begin{array}{l}\text { Asymp. Sig. } \\
\text { (2-sided) }\end{array}$ \\
\hline Pearson Chi-Square & 19.850 & 8 & .011 \\
Likelihood Ratio & 20.511 & 8 & .009 \\
Linear-by-Linear & & & .019 \\
Association & 5.461 & & 1 \\
N of Valid Cases & 206 & & \\
\hline
\end{tabular}

The chi-square test compared the two phases of the study and the result showed that the listening process had influenced the numbers of the strategies which were used in this study $\left(X^{2}=19.85 \& \operatorname{sig}<0.05\right)$.

Cramer's V is a post-test to give additional information and predicts how significant relationship between variables is. Table 4-7 presented the association between variables.

TABLE 8

SYMMETRIC MEASURES

\begin{tabular}{|ll|l|l|}
\hline & & Value & Approx. Sig. \\
\hline Normal by & Phi & .310 & .011 \\
Nominal & Cramer's V & .310 & .011 \\
N of Valid Cases & & 206 & \\
\hline
\end{tabular}

The result showed that the association between variables was 0.31 between 0 and 1 and it means that there is an average association between variables $(\mathrm{V}=0.31 \& \mathrm{Sig}<0.05)$.

\section{CONCLUSIONS AND IMPLICATIONS}

The descriptive analysis showed that the students employed strategies, to serve as a lexical and functional substitute to fill a gap, for maintaining their interactions in communication. This interaction is evident in the number of frequencies employed, in replaying the CNN news samples in the third phase, by the students.

The result of this study showed that, despite the unawareness of communication strategies, when the students could not convey their ideas, students tend to replace the original intent with other easy words or simple expressions. It is undeniable that in an authentic conversation and oral translation, communication breakdowns may occur anytime and communication strategies are accessible tools in hand to help the students obviate their problems.

In line with the findings of Poulisse and Schils (1989), Chen (1990), Wanaruk (2003) and Mei (2010) which investigated the use of communication strategies by learners with different levels of English proficiency, this study had similar results. Most of the participants employed the paraphrase strategy to solve their communicative problems. In real situations, students always encounter difficulties in expressing their meaning. One possible explanation for this is that they are not able to access a word that is actually stored in their memory. They may simply be unable to recall a particular word at a given moment (Mei, 2010). Paraphrase (Approximation, Word coinage, Circumlocution), based on Tarone's model (1977), can help students convey their meanings.

Moreover, most studies also found that the high proficiency students used more efficient strategies (e.g. L2-based strategies and linguistics-based strategies). On the other hand, the low proficiency students employed more inefficient strategies (e.g. avoidance strategies) because of their limited knowledge of the target language (Binhayeearong, 2009).

In contrast to what Huang (2010) found, the result of avoidance strategy ranked in the least used strategy among those strategies which were used in his study.

In the following the significance value obtained by Chi-Square test is $19.85 \& \rho=0.011$ which is less than the determined value of $\propto=0.05$ (chi-square $=19.850, \mathrm{df}=8, \rho=0.011<0.05$ ). A Chi-Square test explains a significant difference between the two samples and Cramer's $V$ value which is $V=0.31$ indicates the amount of association.

Therefore, the null hypothesis was rejected. It means that there is a significant relationship between listening to authentic materials practice and the use of communication strategies.

The results of this study provide the following beneficial implications for compensation in oral translation.

Since the goal of communication among ESL learners is to share meaning to develop communicative competence, the development of strategic competence which helps students handle breakdowns due to the lack of knowledge should be get focused in language learning process. To this end, instructors should help students get familiar with possible and available communication strategies to play their part in classroom activities. It may help students take risk and use these strategies to be in the line of oral translation to prompt the development of strategic competence. The findings showed that students used fillers such as "emm", and intended to use gestures and facial expressions to help convey their message (non-verbal strategies). Communication strategies are essential tools in hand in the time of need to help students avoid breaking down the authentic conversation and having enough time to compensate the original message in oral translation. Furthermore, communication strategies are remedies to fill the gap of non mastered students' background knowledge in the realm of communication and oral translation.

Since language proficiency plays an important role in effective conversation, therefore the learners' different level of proficiency influence employment of communication strategies. In this case the instructor should choose materials 
based on students' level of proficiency that is suitable and appropriate. In addition, it is necessary for instructors to know how high and law proficiency students solve their communicative problems by using communication strategies. As an example most of students prefer to use paraphrase and circumlocution strategies to convey their meaning. It is beneficial for instructors to know and encourage students to use the functional strategies rather than being in peace or asking for assistance. The appropriate use of communication strategies increases the students' communicative competence and it influences students' usage of communication strategies in its turn.

Finally, the instructors should aware students of the importance of employing appropriate communication strategies. Not only some strategies do not enhance students' communication but they make students skip some useful strategies in the favor of the more easy cases. Appropriate examples are avoidance strategies and appeal for assistance. However, these strategies are useful in its exact place to obviate breakdown but the y can be replaced with effective and more functional items when the students face communication difficulties. The awareness of students to get benefit from appropriate strategies helps them appear more effective in any given communication.

\section{REFERENCES}

[1] Bachman, L. F. (1990). Fundamental considerations in language testing. Oxford: Oxford University Press.

[2] Berelson, B \& Steiner, G. A. (1964). Human Behavior. New York: Harcourt, Brace and World.

[3] Berlo, David K. (1960). The Process of Communication: An Introduction to Theory and Practice. USA Holt, Rinehart and Winston Inc.

[4] Bialystok, E. and M. Fröhlich. (1989). Oral communication strategies for lexical difficulties. Interlanguage Studies BulletinUtrecht. 5:3-30

[5] Binhayeearong, T. (2009). Communication Strategies: A Study of Students with High and Low English Proficiency in the M.3 English Program at Attarkiah Islamiah School. Applied Linguistics

[6] Brown, H. (1994). Principles of language learning and teaching. New York: Pearson Education.

[7] Canale, M., \& Swain, M. (1980). Theoretical bases of communicative approaches to second language teaching and testing. Applied Linguistics, 1, 1-47.

[8] Chen, S. (1990). A study of communication strategies in interlanguage production by Chinese EFL learners. Language Learning. 40 (2), 155-187.

[9] Corder, S. P. (1983). Strategies of communication. In C. Faerch \& G. Kasper (eds), Strategies in interlanguage communication. London: Longman.

[10] Dornyei, Z., \& Scott M., L. (1997). Communication strategies in a second language: Definitions and taxonomies. Language Learning.47, 173-210.

[11] Farch, C., \& Kasper, G. (1983a). Plans and strategies in foreign language communication. In C. Færch, \& G. Kasper (Eds.), Strategies in interlanguage communication (pp. 20-60). London: Longman.

[12] Faerch, C. \& Kasper, G. (1983b). Communication strategies in interlanguage production. In C. Faerch \& G. Kasper (eds), Strategies in interlanguage communication. London: Longman. Amsterdam/Philadelphia: John Benjamins Publishing Company.

[13] Gear,J. \& Gear, R.(2006). Cambridge Preparation for the TOFEL test (4th edition). New York: Cambridge University Press.

[14] Huang, Ch. (2010). Exploring Factors Affecting the Use of Oral Communication Strategies. Lunghwa University of Science and Technology.

[15] Jamshidnejad, A. (2011). "Developing Accuracy by Using Oral Communication Strategies in EFL Interactions", Journal of Language Teaching \& Research/17984769

[16] Mei,A. (2010). Use of Communication Strategies by Chinese EFL Learners. Guizhou University

[17] Poulisse, N., \& Schils, E. (1989). The influence of task-and proficiency- relate factors on the use of compensatory strategies:Aquantitative Analysis. Language Learning. 39 (1), 15-48.

[18] Selinker, L. (1972). Interlanguage. IRAL - International Review of Applied Linguistics in Language Teaching, 10, $209-230$.

[19] Tarone, E. (1977). Conscious communication strategies in interlanguage, in H. Douglas B., Carlos Y., and Ruth H. C. (Eds). TESOL. Washington D.C., 194-203.

[20] Tarone, E. (1980). Communication strategies, foreigner talk and repair in interlanguage. Language Learning, 30, $417-431$.

[21] Wannaruk, A. (2003). Communication strategies in an EST context. Studies in Language and Language Teaching, 12, 1-18

Leila Razmjou holds a PhD in TEFL from Tabriz University, Tabriz, Iran. She is an assistant professor in Tabriz University. Razmjou is particularly interested in Translation Pedagogy and has had a number of international conference papers and paper proceedings in this regard. Razmjou's papers have appeared in Journal of Language Teaching and Research, Iranian Journal of Applied Language Studies, and Journal of social sciences and humanities of Shiraz University.

Javad Afsari Ghazi holds an MA in Translation Studies from Islamic Azad University at Central Tehran branch and has been an English teacher in the nonprofit schools for two years. His main area of research interest is teaching communication strategies to the students of different levels of language proficiency. 